\title{
Solving genetic disease at the population scale
}

Barry Merriman ${ }^{1,2}$

From 2nd International Genomic Medical Conference (IGMC 2013)

Jeddah, Kingdom of Saudi Arabia. 24-27 November 2013

I will discuss the latest advances in genome sequencing technology, and the approach to the $\$ 1000$ genome, with a focus on the status of the new Ion Torrent Proton Platform and how this can be applied in a systematic way to solve genetic diseases for entire populations. For this, I will present a process that identifies and removes all the bottlenecks in deploying genomic personalized medicine for entire countries. Examples will be provided based on specific national efforts already underway, in the USA and globally, and I will discuss the requirements that make countries or regions good candidates for this approach, and the opportunities for such countries to begin or accelerate the process.

\author{
Authors' details \\ 'Lead System Architect, Advanced DNA Sequencing Technology, CSO, \\ Enterprise Genomics Group, Life Technologies, Inc., USA. ${ }^{2}$ Department of \\ Human Genetics, UCLA, USA.
}

Published: 2 April 2014

Submit your next manuscript to BioMed Central and take full advantage of:

- Convenient online submission

- Thorough peer review

- No space constraints or color figure charges

- Immediate publication on acceptance

- Inclusion in PubMed, CAS, Scopus and Google Scholar

- Research which is freely available for redistribution 